\title{
The Economic Relevance Of Chief Marketing Officers In Firms' Top Management Teams
}

John Abernathy, Kennesaw State University, USA

Tom Kubick, University of Kansas, USA

Adi Masli, University of Kansas, USA

\begin{abstract}
Management theory suggests that the presence of the Chief Marketing Officer in the Top Management Team reflects a corporate emphasis on marketing and customer relations. Finance theory suggests that this emphasis should translate into additional shareholder wealth. However, prior research has failed to document such a relationship. Using performance attribution analysis, the authors construct a long-short portfolio that buys (sells) stocks of firms with (without) a Chief Marketing Officer in the Top Management Team and find this investment strategy would have earned risk-adjusted excess returns of approximately 3\%. Additional analyses suggest the value of having a Chief Marketing Officer in the Top Management Team manifests primarily among firms with high operating margin, low asset turnover, high profitability, high $R \& D$ intensity and high advertising expenses. The authors conclude that having a Chief Marketing Officer in the Top Management Team has a positive impact on shareholder wealth.
\end{abstract}

Keywords: Chief Marketing Officer; Top Management Team; Shareholder Wealth; Performance Attribution Analysis

\section{INTRODUCTION}

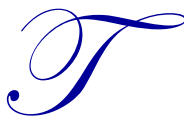

he Chief Marketing Officer's (CMO's) roles include understanding and delivering value to customers, developing and pricing products, and measuring marketing's contribution to the business in relevant and quantifiable terms (Nath and Mahajan, 2008; 2011; Boyd, Chandy, and Cunha, 2010; IBM, 2011). Moreover, the CMO plays a crucial role in advising the CEO and board members about the latest customer preferences and aligning corporate objectives to meet those evolving customer needs (Roll, 2011). Nevertheless, debates continue to exist as to whether the CMO position provides sustainable business value to its organization.

For example, a recent Forbes article proclaims "the Chief Marketing Officer is dead", suggesting that CMOs are increasingly powerless and peripheral (Turpin, 2012). In a recent survey by Fournaise Marketing Group (2011), 73\% of CEOs believe that marketers lack business credibility, are not effective enough in generating incremental customer demand, and are not business growth generators. In this sense, a majority of CEOs doubt whether CMOs are able to demonstrate how the marketing strategies and campaigns they deploy grow their organizations' top line in terms of customer demand, sales, prospects, conversions or market share. As a result, CMOs are under increasing pressure to prove their value and relevance on a daily basis (Magnone, 2011). Accordingly, Spencer Stuart (2004) finds that, among the top 100 branded firms, CMO tenure has fallen to just under 23 months. Further, marketers are losing stature and influence within organizations. A recent Ernst \& Young study of Fortune 1,000 company financial filings notes the lack of head marketers listed among the highest compensated executives (Zmuda, 2009).

On the other side of the debate, proponents of the CMO position claim that the position is crucial to business growth and firm performance. For example, Andrew Hayes, an executive of CMO and CEO recruitment firm Russell Reynolds Associates claims that: 
CMOs are the voice of the customer or consumer, and the champion and guardian of the company's brands. They align their organizations around a clear and compelling brand positioning and promise and ensure consistency of messaging and experience at every single consumer and customer touch point. (Smith, 2012)

Further, David Roman, CMO of Lenovo, affirms that having a strong CMO with a real point of view and a commitment to rigorously and relentlessly delivering breakthrough work from marketing is of great importance (Roberts, 2012).

Court (2007) suggests that the CMO's role actually needs to be broader to keep pace with changing consumer buying behavior, evolving distribution models, and a more diverse and global consumer base. Similarly, Dee Dutta, former CMO of Sony Ericsson, states that the CMO should be put in the position to work with other top executives and members of the board of directors (Roberts, 2012). Andrew Hayes, an executive of CMO and CEO recruitment firm Russell Reynolds Associates, suggests that firms should include the CMO among the highest paid executives because:

CMOs have a very direct impact on shaping business strategy, driving growth and fueling commercial success. They are the architects that shape the company's brand and the conductor that ensures all functions and employees are aligned around the delivery of a consistent and differentiated brand experience. The companies that figure this out and value the CMOs role accordingly will attract and retain the stars. The rest will get what's left. (Smith, 2013)

In this study, we contribute to the debate by examining whether the presence of a CMO in the top management team (TMT) provides value to shareholders. We define a CMO to be a member of the TMT if he or she is one of the top five highest paid executives of the firm, in line with prior research that links compensation to influence within the organization (e.g., Finkelstein, 1992; Finkelstein and Hambrick, 1996; Carpenter and Sanders, 2002; Bertrand and Schoar, 2003; Boyd et al., 2010). Members of the top five executives are most likely to be responsible for firm strategy, spending and resource allocation decisions, and product and capital-market outcomes (Currim, Lim, and Kim 2012). Accordingly, a CMO that is among the top five executives is more likely to have stature and gain access to the CEO (and other key top executives), which offers him or her the opportunity to influence significant corporate decisions and strategies as they are formulated and implemented. Thus, the presence of the CMO in the TMT is an indicator of both the status of marketing and the corporate adoption of the marketing concept (Hise, 1965; Piercy, 1986; Webster, Malter, and Ganesan, 2003, Boyd et al., 2010).

Despite theory suggesting that CMO influence will impact firm value, extant academic research has not documented such an association. For example, in a sample of 88 new CMO appointment announcements, Boyd et al. (2010) find no association between the appointments of the CMO to one of the top five highest paid officers and short-run abnormal stock returns. Nath and Mahajan (2008) find that the presence of a CMO in the TMT of a firm had no significant effect on Tobin's q or sales growth, common proxies for investment opportunities. Similarly, Nath and Mahajan (2011) find that CMO power has no significant effect on firm performance as measured by return on sales and sales growth.

Unlike previous studies on CMO influence, our study adopts a long-horizon approach to examine the economic relevance of having a CMO in the TMT for a large sample of firms. Prior studies examine various financial performance measures which often fail to capture the intangible nature of marketing activity. That is, there may not be a direct link between marketing activity and financial performance measures. In addition, it is difficult for stock market participants to assess the true quality of marketing activity. In this paper, we argue that the presence of the CMO in the TMT acts as a signal to shareholders about the quality and commitment of the firm to its marketing activities. Our long-horizon approach allows the market to revise expectations that may not be fully incorporated in a short window surrounding the promotion announcement or may not be directly reflected in financial performance measures.

We construct a value-weighted, long-short portfolio that buys stocks of firms that report a CMO among the top five highest paid executives and sells stocks of firms that do not. We then estimate a monthly time-series regression throughout our sample period, controlling for standard risk factors (Fama and French, 1993; Carhart, 1997). The long-run value attributable to this portfolio strategy is captured by the intercept (or "alpha") in our regression model. The intuition behind this methodology is that, in equilibrium, forming a long-short portfolio on a 
firm characteristic has an expected excess return ("alpha") of zero, unless that characteristic has a systematic effect on firm value.

Our empirical design has a long tradition in the accounting and finance literature investigating the economic relevance of certain firm characteristics such as momentum (Carhart, 1997), corporate governance (Gompers, Ishi, and Metrick, 2003), earnings management (Bhojraj, Hribar, Picconi, and McInnis, 2009), and deceptive conference calls (Larcker and Zakolyukina, 2012). We also investigate whether the performance of our long-short CMO portfolio is contingent upon characteristics of the firm's strategic positioning, such as product differentiation, profitability, innovation (R\&D intensity), and the magnitude of advertising expenses. We confirm the portfolio returns manifest in firms where a CMO would theoretically be of greater value (e.g., Gupta, Raj, and Wilemon, 1986; Selling and Stickney, 1989; Homburg, Workman, and Krohmer, 1999).

Using a sample of publicly traded companies from 1993 - 2007, we identified firms that have their CMO listed as one of the top five highest paid executives and those that do not. During the sample period, the CMO was disclosed in the annual proxy filing as being among the top five highest paid corporate officers for 2,746 firm-year observations, representing approximately $10 \%$ of our total sample. Results from our primary empirical tests reveal that forming a portfolio that buys (sells) stocks of firms with (without) a CMO in the top management team yielded an average monthly excess return ("alpha") of $.257 \%$ during our sample period. This monthly return translates to an annualized return of approximately $3 \%$ after compensating for risk. Mechanically, the alpha from our time series regression reflects the value of having a CMO in the TMT, while the other coefficient estimates reflect exposures to other factors that have been shown to impact portfolio returns (i.e., overall market return, size, book-to-market, and momentum). Our results provide evidence that the presence of a CMO in the TMT is economically relevant to shareholders of the firm.

When we partition the portfolio further to investigate the specific roles played by the CMO, we find the statistically positive alpha manifests among firms with high operating margin, low asset turnover, high profitability, high R\&D expense, and high advertising expense, all channels through which prior research suggests the CMO exercises considerable influence. ${ }^{1}$

Our study makes several contributions to the literature. We add to the academic literature investigating the impact of CMOs on firm value. Prior research provides mixed evidence on this issue, with some work suggesting that the presence and/or prominence of a CMO does not affect firm performance (Nath and Majan, 2008, 2011; Weinzimmer et al., 2003). Furthermore, empirical evidence on the effect of CMO prominence on equity prices or stock returns is scant, but emerging. Recently, Boyd et al. (2010) examine a sample of 88 CMO appointment announcements and employ an event-study methodology to examine the effect of CMO appointment announcements on abnormal stock returns surrounding the announcement dates. The authors find that in $46 \%$ of the cases in their sample, the stock market response to the appointment of a CMO was positive, whereas in $54 \%$ of the cases, the response was negative. In addition, Boyd et al. (2010) do not find that CMO influence (i.e., a CMO within top five highest paid executive cohort) significantly affects abnormal stock returns. Such results imply that capital market participants may not value CMO appointments to the TMT.

We contribute to this nascent line of research by taking a long-horizon approach to examine the economic relevance of CMOs. In essence, we employ a long-run event study examining whether companies that include their CMO in the TMT outperform those that do not. By taking a long-run approach, we allow the market to revise expectations that may not be fully incorporated in a short window surrounding the promotion announcement. Second, we demonstrate that the link between CMO top managerial status and firm value is contingent on various contextual factors. Specifically, we provide evidence that the effect of CMO top managerial status on firm value is contextual upon firm strategic positioning, profitability, innovation, and magnitude of advertising expenditures.

Our study also informs practitioners in the marketing profession, boards of directors, executives, and investors as to whether the CMO position offers tangible value to the organization. While some have argued that the CMO position is fading and losing its importance, others maintain that CMOs need to be more involved in the

1“High" ("low") is interpreted as being in the top (bottom) two quartiles ranked on the contextual characteristic by year and industry (three-digit SIC).

2013 The Clute Institute 
strategic decision-making process alongside the CEO and other top executives. Using our long-horizon specification, we document that having a CMO on the TMT is economically beneficial to shareholders.

In the next section, we review the related research and develop the hypotheses. We then describe the sample selection process and detail our research methodology. Finally, we provide a discussion of our results, their implications for theory and practice, and a brief conclusion to our study, including suggestions for future research.

\section{BACKGROUND AND HYPOTHESIS DEVELOPMENT}

\section{CMO Importance within the Organization}

“Today's customers can shop around the globe, find out more than ever before about the organizations they're dealing with, and share their views with hundreds of thousands, if not millions, of fellow customers. Their expectations - be they consumers, citizens or business customers - are soaring. And they can make or break brands overnight" (IBM, 2011, p. 2).

Fulfilling customer demands in today's competitive landscape has become a top priority. Consequently, no other corporate function has evolved more dramatically than marketing, where marketing is continuously being asked to fulfill more significant and strategic roles with implications for the entire enterprise (Court, 2007). Financial theory supports the value relevance of marketing because marketing impacts the shape of the probability distribution of future sales revenues (Rao and Bharadwaj, 2008; Kumar and Shah, 2009).

The CMO can be the strategic connection between the corporate boardroom, the top management team (TMT), the CEO, and the customer (Roll, 2011). Therefore, companies should ideally offer the CMO the requisite status and power within their firms in order for CMOs to take part in guiding the company's vision and mission (Nath and Mahajan, 2008). For example, Banks (2009) opines that the CMO is one of the senior executives best equipped to fully lead the modern corporation - i.e., a "CEO candidate." Given adequate influence within the enterprise, CMOs have a great opportunity to transform their marketing team from order takers to collaborators, partnering with business units to drive the bottom line (Forrester Research and Heidrick \& Struggles, 2011). This is consistent with calls from both academics and practitioners for the CMO's role to evolve into one that is more strategically partnered with decision-makers within the firm (Court, 2007; McGovern and Quelch, 2004; Silver, 2003).

\section{CMO Top Managerial Status and Firm Value}

A firm's corporate strategy, which includes major resource allocations, organizational redesign, acquisitions, divestments, and entering or exiting major markets, is largely driven by the TMT (Cyert and March, 1963; Hambrick and Mason, 1984; Varadarajan and Clark, 1994). Consequently, prior researchers have referred to the presence of the CMO in the TMT as an indicator of both the corporate status of marketing and the corporate adoption of the marketing concept (Hise, 1965; Mann, 1971; Piercy, 1986; Webster, 1981; Webster, Malter, and Ganesan, 2003, Nath and Mahajan, 2008). However, recent studies show that only about seven percent of Fortune 1000 firms list the head marketer in the TMT and only approximately $47 \%$ of Fortune 1000 firms have a CMO at all (Zmuda, 2009; Hyde, Landry, and Tipping, 2004).

Michel and Hambrick (1992) identify marketing as a critical functional area of expertise necessary for a TMT to create shareholder value. Similarly, Webster (1992) suggests that marketing's role in the TMT is to assess market attractiveness, represent the customer's point of view, and develop and promote the firm's overall value proposition throughout the firm and in the marketplace. In sum, marketing contributes to customer, and ultimately shareholder, value by contributing to the development of customer-oriented solutions and connecting the firm to the market.

Accordingly, the customer and competitor focus of a CMO should enhance the TMT's ability to improve the firm's capabilities and deliver superior customer value (Anderson, 1982; Srivastava et al., 1998, 1999; Webster, 1992). In addition, as a member of the TMT, the CMO has the ability to shape the marketing strategies and activities consistently with firm-level goals and strategies. This is important because Slater and Olson (2001) suggest that 
superior financial performance occurs only when marketing strategies are carefully aligned with overall business strategies. Despite the above discussion, empirical research fails to document a relation between marketing's inclusion in the TMT and firm value. Thus, we test the following hypothesis:

H1: Having a CMO in the TMT is positively associated with firm value.

\section{Product Differentiation and Cost Leadership}

Porter (1980) presents a framework describing two generic strategies that a firm can use to achieve competitive advantage - cost leadership and product differentiation. Firms adopting the cost leadership strategy aim to increase market share based on creating a low-cost position relative to their peers. To achieve cost leadership, a firm must perform activities creating, producing, selling and delivering products and services faster, cheaper, and with fewer inputs than their rivals. Firms generally adopt large scale facilities, process improvements, cost minimization, and overhead control to implement a cost leadership strategy. Cost leaders can achieve above-average returns by charging low prices for their products and seeking out customers who care more about price than about image or novelty.

On the other hand, firms adopting the product differentiation strategy achieve a competitive advantage by providing products or services that offer unique qualities desirable to customers which allow the firm to command a price premium. Because CMOs are charged with managing customer relationships and are involved in product planning, development, and pricing (Boyd et al., 2010; IBM, 2011; Roberts, 2012), the success of a product differentiation strategy is likely to require the leadership of a CMO. Product differentiators are firms that command higher margins as returns for their superior product/service quality or greater customer intimacy (Selling and Stickney, 1989). In this light, having a CMO in the TMT will be more valuable for firms with high operating margins. Our second hypothesis is as follows:

H2: Having a CMO in the TMT is positively associated with firm value for firms with high operating margins.

Cost leaders must sustain operational efficiency to be the lowest cost producer (Selling and Stickney, 1989). Since cost leaders utilize their assets efficiently, they must maintain lean operations and high asset turnover (e.g., Fairfield and Yohn, 2001). Product differentiators, on the other hand, command a premium price in the market by offering higher quality products. These firms have lower asset turnover in addition to higher operating margins. We contend that the value of a CMO in the TMT will be more valuable for product differentiation firms that have lower asset turnover. Therefore, we formulate our third hypothesis as follows:

H3: Having a CMO in the TMT is positively associated with firm value for firms with low asset turnover.

\section{Firm Profitability}

Furthermore, firms that differentiate their products earn greater profits. Banker et al. (2006) find that the differentiation strategy allows a firm to sustain financial performance to a greater extent than an efficiency strategy. A firm pursuing a differentiation strategy is likely to create a unique perception of its products and services, enabling it to command above-market prices and greater profitability (Kotha and Vadlamani, 1995; Porter, 1980). Therefore, a higher profitability, as measured by return on assets, is likely to be associated with a differentiation strategy (Kotha and Nair, 1995). Our fourth hypothesis is:

H4: Having a CMO in the TMT is positively associated with firm value for firms with higher profitability.

\section{Product Innovation}

A strategy of differentiation is usually accomplished through product-specific innovations. However, investing in new products and services through research and development (R\&D) is inherently unpredictable (Barker and Mueller, 2002). In response to this uncertainty, the firm must allocate resources based on future expectations (Eisenhardt and Bourgeois, 1988; Yadav, Prabhu, and Chandy, 2007). The success of the firm is then driven, in large part, by correctly anticipating customer needs and wants (Gupta, Raj, and Wilemon, 1986). 
Therefore, the role of CMO is critical for firms with high R\&D expense by providing insights into potential segments and customer-linking capabilities. Homburg, Workman, and Krohmer (1999) argue that marketing's role and influence are more critical in high R\&D firms. The preceding argument suggests that the role of the CMO is more pertinent to firm value for firms that aggressively pursue R\&D investments. This leads us to the following hypothesis:

H5: Having a CMO in the TMT is positively associated with firm value for firms with high R\&D expense.

\section{Advertisement Spending}

Finally, firms differentiate their products from their competitors' by trademarks or advertising. The role of advertising is to improve consumer perceptions of the attributes in traded commodities, which makes brands within a product category appear more differentiated to consumers, increasing total demand (Dixit and Norman, 1978). The $\mathrm{CMO}$, as head of marketing strategy, is intimately involved in a firm's ability to differentiate its products. Accordingly, our final hypothesis is as follows:

H6: Having a CMO in the TMT is positively associated with firm value for firms with high advertising expense.

\section{SAMPLE AND RESEARCH METHODOLOGY}

\section{CMO Top Managerial Status}

Consistent with prior research linking executive compensation to influence within the organization (e.g., Finkelstein, 1992; Finkelstein and Hambrick, 1996; Carpenter and Sanders, 2002; Bertrand and Schoar, 2003; Boyd et al., 2010), we identify a CMO as having top managerial status when he or she is one of the top five highest paid executives of the firm. Our rationale is that the top five executives are usually part of a senior management team ultimately responsible for firm strategy, spending and resource allocation decisions, and product and capital-market outcomes (Currim et al., 2012). ${ }^{2}$ We limit our sample to the ExecuComp database because it provides yearly data on the compensation of the top five executives. The ExecuComp database covers current, historic, and total compensation data on the top five executives of companies in Standard \& Poor's S\&P 500, S\&P 400 MidCap, and S\&P 600 SmallCap indexes (Currim et al., 2012). We search executives that are listed among the top five highest paid executives during the year and identify whether an individual holding the CMO title is among the top five. Specifically, an executive in the top five with the term "marketing" in his or her title constitutes CMO presence (Nath and Mahajan, 2008). We refer to firms with a CMO in the top five as "CMO firms" and firms without a CMO in the top five as "non-CMO firms." Based on this distinction, we create a binary variable, CMO_TOP5, which equals one for CMO firms and zero for non-CMO firms.

\section{Firm Strategy}

We use several objective indicators to measure a firm's strategic position. First, we use the DuPont method for decomposing ROA into profit margin and asset turnover (Fairfield and Yohn, 2001; Nissim and Penman, 2001) to use common accounting ratios to capture Porter's (1980) two generic strategies, specifically profit margin for differentiation and asset turnover for cost leadership (Selling and Stickney, 1989). Operating income over sales (OPIS) measures the profit margin and is used to capture a firm's differentiation strategy. Since cost leaders efficiently utilize their assets to generate sales, sales over assets is used as a proxy for such firms.

In addition, differentiators offer products and services with unique features that customers find valuable. These features can be superior designs, innovative research and development, superior engineering, customer intimacy, and brand image (Porter, 1980, 1996). Differentiation is achieved by leading scientific research, advanced R\&D and product development, and superior customer service (Hambrick and Mason, 1984). A differentiation strategy allows firms to command high margins by creating customer value (Kald, 2003). Therefore, we also use profitability, R\&D expense, and advertising expense as proxies for product differentiation.

\footnotetext{
${ }^{2}$ For some firm-years, ExecuComp provides more than five executives. For firm-years with more than five executives listed in ExecuComp, we eliminate executives that are not among the top five highest paid cohorts.
} 


\section{Constructing the Long-Short Portfolio}

We adopt a portfolio approach to examine the long-term economic relevance of having a CMO within the TMT. To do this, we construct a portfolio that buys (sells) stocks of firms with (without) a CMO among the top five highest compensated officers disclosed in the annual proxy filing. The portfolio is potentially rebalanced every fiscal year; for example, firms that disclose a CMO within the TMT during one fiscal year enter the portfolio, but may leave the portfolio if the CMO is absent in the following, or some future, year. That determination is made each fiscal year. To ensure data (i.e., annual financial statements and proxy filings) are publicly available, we evaluate firms four months after fiscal year end. Thus, a firm that has a December 31 fiscal year end and discloses a CMO within the TMT in the annual proxy filing (sometime between January 1 and April 30 of the following year) will enter the portfolio as of May 1 of the following year. That firm will remain in the portfolio so long as all future proxy filings indicate a CMO within the TMT. To avoid inadvertently choosing stocks (based on some other factor) to sell, we construct the portfolio with the assumption that each CMO-firm that is purchased is paid for by randomly choosing a non-CMO firm(s) to sell, thus rendering the portfolio a 'zero net investment'.

We subtract the value-weighted monthly return of all non-CMO firms from the value-weighted monthly return of all CMO firms to obtain the monthly return of the CMO portfolio. For our study, the universe of firms that are classified as either CMO firms or non-CMO firms is obtained by the intersection of the Compustat North American, CRSP, and ExecuComp databases. In other words, we evaluate all domestically traded, U.S. firms within the S\&P $1500 .{ }^{3}$ Beyond those constraints, the only other data requirements we impose are that firms have nonmissing values needed to compute operating margin, asset turnover, profitability, $R \& D$ expense, or advertising expense.

\section{Performance Attribution Analysis}

Our multivariate empirical design is essentially a performance attribution analysis of the CMO long-short portfolio. We are interested in the excess return generated by firms with CMOs in the TMT versus firms that do not have a CMO within the TMT. To that end, we test our hypotheses by estimating the following monthly time series regression:

$\mathrm{CMO}_{\mathrm{t}}=\alpha+\beta_{1} \mathrm{RMRF}_{\mathrm{t}}+\beta_{2} \mathrm{SMB}_{\mathrm{t}}+\beta_{3} \mathrm{HML}_{\mathrm{t}}+\beta_{4} \mathrm{UMD}_{\mathrm{t}}+\varepsilon_{\mathrm{t}}$

$\mathrm{CMO}_{\mathrm{t}}$ is the value-weighted return for month $\mathrm{t}$ for a long-short portfolio that buys (sells) stocks of firms with (without) a CMO within the top management team as disclosed in the most recent annual proxy filing. $\mathrm{RMRF}_{\mathrm{t}}$ is the return on the market portfolio minus the risk-free rate for month $\mathrm{t} . \mathrm{SMB}_{\mathrm{t}}$ is the factor-mimicking portfolio return during month $\mathrm{t}$ for a portfolio that buys (sells) stocks with small (big) market capitalizations. $\mathrm{HML}_{\mathrm{t}}$ is the factormimicking portfolio return during month $\mathrm{t}$ for a portfolio that buys (sells) stocks with high (low) book-to-market value of equity ratios. $\mathrm{UMD}_{\mathrm{t}}$ is the factor-mimicking portfolio return during month that buys (sells) stocks with positive (negative) short-term performance. ${ }^{4}$

By specifying the return generating process in Equation 1 to include four factors, we are allowing the performance of the CMO portfolio to be described by common factors that prior research has determined to affect most stocks. Thus, the term of interest in Equation 1 is $\alpha$. In equilibrium, the expected value of $\alpha$ is zero, unless the portfolio being examined (in our case $\mathrm{CMO}$ ) is constructed by some relevant value driver. In other words, the value attributable to having a CMO within the TMT must be incremental to the portfolio's sensitivity to the overall market (RMRF), the size of firms in the portfolio (SMB), underlying growth opportunities of firms in the portfolio (HML), or short-term performance momentum (UMD) of the portfolio. Hence, we are interested in the excess return $(\alpha)$.

\footnotetext{
${ }^{3}$ ExecuComp constrains the sample by tracking only firms in the S\&P 1500.

${ }^{4}$ Monthly factor-mimicking returns for RMRF, SMB, HML, and UMD (commonly referred to as the four-factor model) are obtained from the WRDS database. These portfolios have been used extensively in prior research. Specific details on how these portfolios are constructed are documented in Fama and French (1993) and Carhart (1997).
} 


\section{RESULTS}

\section{Sample Composition}

Table 1 presents a breakdown of our sample. There were $2,746(22,740)$ monthly observations with (without) a CMO in the TMT during our sample period from February 1993 through December 2007. We choose February 1993 as the beginning of our sample period as ExecuComp began tracking firms during fiscal year 1992 and these firms are included (at the earliest) as of February 1993 (four months after the first fiscal year end for a CMO firm to ensure data are publicly available). We choose December 2007 as the end of our sample period in order to purge the confounding effects of the global financial crisis that occurred during 2008 and 2009. Table 1 indicates that the distribution of CMO firms consistently represented approximately $10 \%$ of the sample.

Table 1: Breakdown of CMOs among the Top Five Highest Paid Executives by Fiscal Year

\begin{tabular}{|c|c|c|c|c|}
\hline \multirow[b]{2}{*}{ Year } & \multicolumn{2}{|c|}{ CMO_TOP5 = 1} & \multicolumn{2}{|c|}{ CMO_TOP5 $=0$} \\
\hline & Frequency & $\%$ & Frequency & $\%$ \\
\hline 1993 & 99 & $8.56 \%$ & 1,058 & $91.44 \%$ \\
\hline 1994 & 161 & $10.38 \%$ & 1,390 & $89.62 \%$ \\
\hline 1995 & 165 & $10.31 \%$ & 1,435 & $89.69 \%$ \\
\hline 1996 & 156 & $9.45 \%$ & 1,495 & $90.55 \%$ \\
\hline 1997 & 171 & $10.22 \%$ & 1,503 & $89.78 \%$ \\
\hline 1998 & 175 & $10.11 \%$ & 1,556 & $89.89 \%$ \\
\hline 1999 & 195 & $10.77 \%$ & 1,616 & $89.23 \%$ \\
\hline 2000 & 213 & $11.89 \%$ & 1,579 & $88.11 \%$ \\
\hline 2001 & 184 & $11.01 \%$ & 1,487 & $88.99 \%$ \\
\hline 2002 & 189 & $11.28 \%$ & 1,486 & $88.72 \%$ \\
\hline 2003 & 210 & $12.05 \%$ & 1,533 & $87.95 \%$ \\
\hline 2004 & 217 & $12.39 \%$ & 1,535 & $87.61 \%$ \\
\hline 2005 & 210 & $11.98 \%$ & 1,543 & $88.02 \%$ \\
\hline 2006 & 202 & $10.80 \%$ & 1,668 & $89.20 \%$ \\
\hline 2007 & 199 & $9.68 \%$ & 1,856 & $90.32 \%$ \\
\hline TOTAL & 2,746 & & 22,740 & \\
\hline
\end{tabular}

\section{Summary Statistics}

Table 2 reports some basic descriptive statistics for our primary variables of interest. Our sample spans February 1993 through December 2007, comprising 179 consecutive months. The mean monthly return for the CMO portfolio is approximately $.134 \%$, while the median monthly return is $.002 \%$. Further, the standard deviation of monthly returns and overall spread for the CMO portfolio is smaller than the four factor-mimicking portfolio returns used to specify Equation 1.

Table 2: Summary Statistics

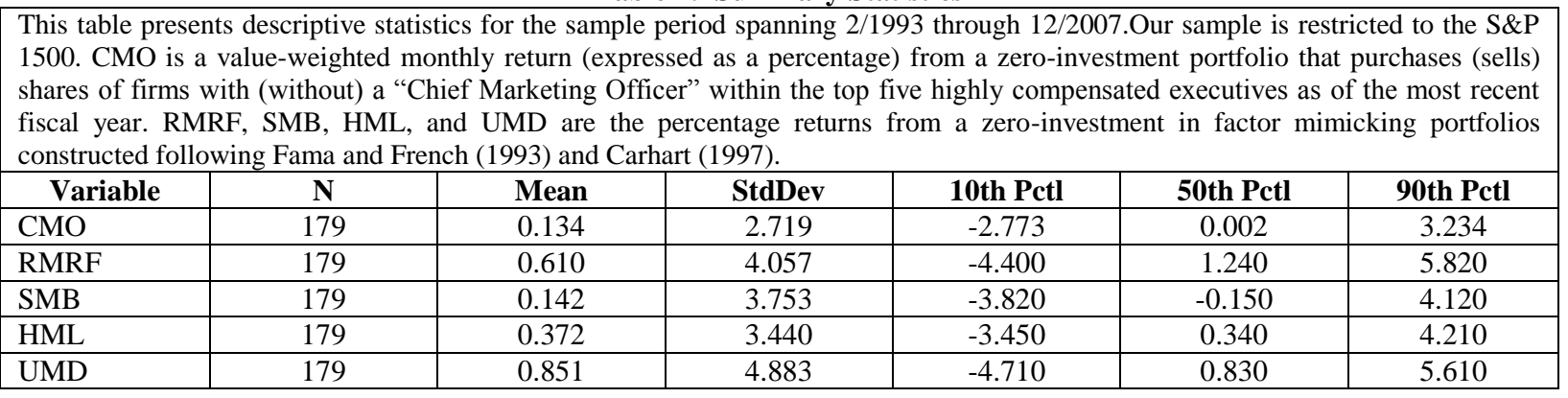




\section{Correlations}

Table 3 reports pair-wise correlations between the CMO portfolio and the four factor-mimicking portfolios. Correlation coefficients indicate the CMO portfolio is positively correlated with the overall market return (RMRF) and the size factor-mimicking portfolio (SMB), but negatively correlated with the factor-mimicking portfolio that buys (sells) shares of firms with high (low) book-to-market ratios (HML). Further, the CMO portfolio is uncorrelated (using a two-sided test and a 5\% significance level) with the momentum factor (UMD). These pairwise correlations suggest that the CMO portfolio is sensitive to the overall market return and has an exposure to small cap stocks and stocks with high growth opportunities.

Table 3: Correlations

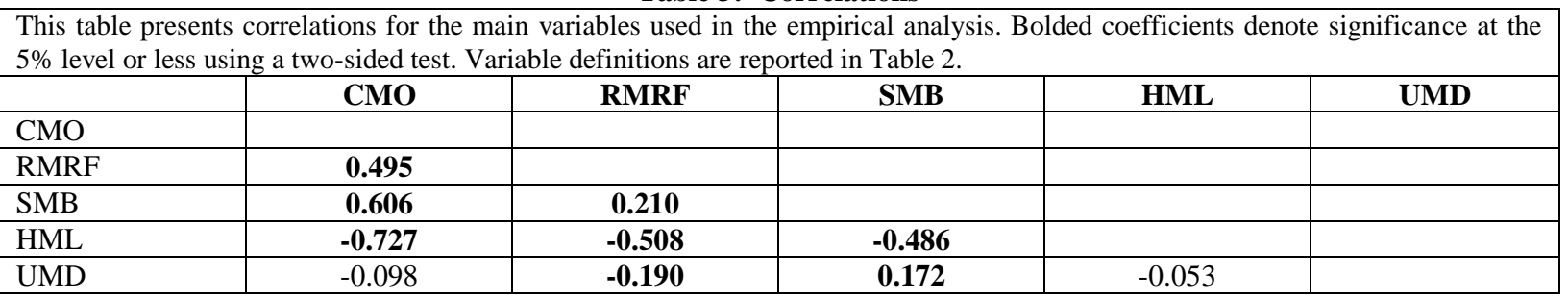

\section{Main Results}

Table 4 presents our primary results. The average monthly excess return $(\alpha)$ of the CMO portfolio is $.257 \%$ and is statistically significant $(p=.045)$, which provides support for H1. This translates to an annualized alpha of $3.08 \%$ which is economically large after controlling for exposures to conventional value drivers (i.e., market return, size, growth opportunities, and momentum). Examining the other coefficient estimates indicates that the CMO portfolio had positive exposure to the overall market portfolio (Estimate $=.095, p=.008$ ), positive exposure to small stocks (Estimate $=.267, p<.0001)$, negative exposure to high book-to-market stocks (Estimate $=-.383, p<.0001$ ), and negative exposure to the momentum factor (Estimate $=-.089, p=.001)$. Further, the high adjusted $\mathrm{R}^{2}(65 \%)$ suggests that we explained a large portion of the variation of the CMO portfolio by the exposure to the four factors specified in the model.

Table 4: Value Premium of CMO Status for Overall Sample This table presents results from estimating the following time series regression: $\mathrm{CMO}_{\mathrm{t}}=\alpha+\beta_{1} \mathrm{RMRF}_{\mathrm{t}}+\beta_{2} \mathrm{SMB}_{\mathrm{t}}+\beta_{3} \mathrm{HML}_{\mathrm{t}}+$ $\beta_{4} \mathrm{UMD}_{\mathrm{t}}+\varepsilon_{\mathrm{t}} . \mathrm{CMO}_{\mathrm{t}}$ is a value-weighted monthly return from a zero-investment portfolio that purchases (sells) shares of firms with (without) a "Chief Marketing Officer" within the top five highly compensated executives as of the most recent fiscal year. All other variables are defined in Table 2. The sample period spans February 1993 through December 2007.

\begin{tabular}{|l|c|c|}
\hline \multicolumn{1}{|c|}{ Variable } & Estimate & p-value \\
\hline Alpha & 0.257 & 0.045 \\
\hline RMRF & 0.095 & 0.008 \\
\hline SMB & 0.267 & $<.0001$ \\
\hline HML & -0.383 & $<.0001$ \\
\hline UMD & -0.089 & 0.001 \\
\hline Adj R-squared & 0.65 & \\
\hline N & 179 & \\
\hline
\end{tabular}

\section{Additional Analyses}

In this section, we partition the data on channels through which prior research suggests the CMO exercises considerable influence (i.e., strategic positioning). In Table 5 (Panel A), we re-estimate Equation 1 by splitting the sample by firms with high and low operating margin. We define operating margin as operating income before depreciation (Compustat OIBDP) divided by sales (Compustat SALE). Observations are classified as having high (low) operating margin if the observation is in the top (bottom) two quartile ranks for that particular fiscal year and industry (three-digit SIC).$^{5}$ Results suggest that the statistically positive alpha is present only among firms with high operating margin $(\alpha=.357, p=.031)$, which provides support for $\mathrm{H} 2$.

\footnotetext{
${ }^{5}$ Missing observations are omitted from the ranking procedure.
} 
In Table 5 (Panel B), we re-estimate Equation 1 by splitting the sample by firms with high and low asset turnover. Asset turnover is defined as sales over total assets (Compustat SALE/Compustat AT). Observations in the top (bottom) two quartile ranks are classified as high (low) asset turnover. Results indicate the statistically positive alpha manifests only among observations with low asset turnover $(\alpha=.677, p=.018)$, which is consistent with $\mathrm{H} 3$.

Table 5: Panel A - Value Premium of CMOs Across Operating Margin

\begin{tabular}{|c|c|c|c|c|}
\hline \multirow{3}{*}{\multicolumn{3}{|c|}{$\begin{array}{l}\text { This table presents results from estimating the following time series regression: Cl } \\
\beta_{4} \mathrm{UMD}_{\mathrm{t}}+\varepsilon_{\mathrm{t}} \text {. CMO } \mathrm{C}_{\mathrm{t}} \text { is a value-weighted monthly return from a zero-investment portf } \\
\text { (without) a "Chief Marketing Officer" within the top five highly compensated executi } \\
\text { variables are defined in Table 2. High (low) operating margin is defined as firms that } \\
\text { each industry (using three-digit SIC code) and year. } \\
\end{array}$}} & \multirow{2}{*}{\multicolumn{2}{|c|}{$\begin{array}{l}+\beta_{1} \mathrm{RMRF}_{\mathrm{t}}+\beta_{2} \mathrm{SMB}_{\mathrm{t}}+\beta_{3} \mathrm{HM} \\
\text { purchases (sells) shares of firms } \\
\text { the most recent fiscal year. All } \\
\text { te top (bottom) two quartile rank } \\
\text { Low Operating Margin }\end{array}$}} \\
\hline & & & & \\
\hline & & & Estimate & p-value \\
\hline Alpha & 0.357 & 0.031 & 0.054 & 0.772 \\
\hline RMRF & 0.054 & 0.241 & 0.152 & 0.004 \\
\hline SMB & 0.255 & $<.0001$ & 0.259 & $<.0001$ \\
\hline HML & -0.362 & $<.0001$ & -0.385 & $<.0001$ \\
\hline UMD & -0.039 & 0.242 & -0.096 & 0.012 \\
\hline Adj R-squared & 0.48 & & 0.49 & \\
\hline $\mathrm{N}$ & 176 & & 179 & \\
\hline
\end{tabular}

Table 5: Panel B - Value Premium of CMOs Across Asset Turnover

This table presents results from estimating the following time series regression: $\mathrm{CMO}_{\mathrm{t}}=\alpha+\beta_{1} \mathrm{RMRF}_{\mathrm{t}}+\beta_{2} \mathrm{SMB}_{\mathrm{t}}+\beta_{3} \mathrm{HML}_{\mathrm{t}}+$ $\beta_{4} \mathrm{UMD}_{\mathrm{t}}+\varepsilon_{\mathrm{t}} . \mathrm{CMO}_{\mathrm{t}}$ is a value-weighted monthly return from a zero-investment portfolio that purchases (sells) shares of firms with (without) a "Chief Marketing Officer" within the top five highly compensated executives as of the most recent fiscal year. All other variables are defined in Table 2. High (low) asset turnover is defined as firms that are in the top (bottom) two quartile ranks for each industry (using three-digit SIC code) and year.

\begin{tabular}{|l|c|c|c|c|}
\hline & \multicolumn{2}{|c|}{ High Asset Turnover } & \multicolumn{2}{c|}{ Low Asset Turnover } \\
\hline Variable & Estimate & p-value & Estimate & p-value \\
\hline Alpha & 0.117 & 0.417 & 0.677 & 0.018 \\
\hline RMRF & 0.097 & 0.016 & 0.119 & 0.133 \\
\hline SMB & 0.284 & $<.0001$ & 0.278 & 0.001 \\
\hline HML & -0.271 & $<.0001$ & -0.419 & $<.0001$ \\
\hline UMD & -0.056 & 0.053 & -0.074 & 0.193 \\
\hline Adj R-squared & 0.53 & & 0.31 & \\
\hline N & 179 & & 176 & \\
\hline
\end{tabular}

In Table 6, we re-estimate Equation 1 for observations that have high and low profitability. We define profitability as return on assets (Compustat IB/Compustat AT). Observations are classified as having high (low) profitability if the observation is in the top (bottom) two quartile ranks for that particular fiscal year and industry (three-digit SIC). Results suggest the statistically positive alpha manifests primarily among firms with high return on assets $(\alpha=.337, p=.031)$, which provides support for $\mathrm{H} 4$.

Table 6: Value Premium of CMOs Across Profitability

This table presents results from estimating the following time series regression: $\mathrm{CMO}_{\mathrm{t}}=\alpha+\beta_{1} \mathrm{RMRF}_{\mathrm{t}}+\beta_{2} \mathrm{SMB}_{\mathrm{t}}+\beta_{3} \mathrm{HML}_{\mathrm{t}}+$ $\beta_{4} \mathrm{UMD}_{\mathrm{t}}+\varepsilon_{\mathrm{t}} \cdot \mathrm{CMO}_{\mathrm{t}}$ is a value-weighted monthly return from a zero-investment portfolio that purchases (sells) shares of firms with (without) a "Chief Marketing Officer" within the top five highly compensated executives as of the most recent fiscal year. All other variables are defined in Table 2. High (low) profitability is defined as firms that are in the top (bottom) two quartile ranks based on return on assets for each industry (using three-digit SIC code) and year.

\begin{tabular}{|l|c|c|c|c|}
\hline & \multicolumn{2}{c|}{ High Profitability } & \multicolumn{2}{c|}{ Low Profitability } \\
\hline Variable & Estimate & p-value & Estimate & p-value \\
\hline Alpha & 0.337 & 0.031 & 0.055 & 0.768 \\
\hline RMRF & 0.066 & 0.129 & 0.132 & 0.012 \\
\hline SMB & 0.302 & $<.0001$ & 0.204 & 0.000 \\
\hline HML & -0.299 & $<.0001$ & -0.425 & $<.0001$ \\
\hline UMD & -0.010 & 0.753 & -0.123 & 0.001 \\
\hline Adj R-squared & 0.51 & & 0.48 & \\
\hline N & 176 & & 179 & \\
\hline
\end{tabular}


We also re-estimate Equation 1 by partitioning the sample on R\&D intensity and advertising expenditures. Table 7 presents results from partitioning the data on R\&D intensity. Firms are classified as having high (low) R\&D intensity if their R\&D expense as a percentage of sales (Compustat XRD/Compustat SALE) is in the top (bottom) two quartile ranks for that particular fiscal year and industry. Results indicate the value of having a CMO in the TMT manifests primarily among firms with high R\&D intensity, which is consistent with $\mathrm{H} 5(\alpha=.305, p=.041)$.

Table 7: Value Premium of CMOs Across R\&D Expense

This table presents results from estimating the following time series regression: $\mathrm{CMO}_{\mathrm{t}}=\alpha+\beta_{1} \mathrm{RMRF}_{\mathrm{t}}+\beta_{2} \mathrm{SMB}_{\mathrm{t}}+\beta_{3} \mathrm{HML}_{\mathrm{t}}+$ $\beta_{4} \mathrm{UMD}_{\mathrm{t}}+\varepsilon_{\mathrm{t}} . \mathrm{CMO}_{\mathrm{t}}$ is a value-weighted monthly return from a zero-investment portfolio that purchases (sells) shares of firms with (without) a "Chief Marketing Officer" within the top five highly compensated executives as of the most recent fiscal year. All other variables are defined in Table 2. High (low) $R \& D$ expense is defined as firms that are in the top (bottom) two quartile ranks for each industry (using three-digit SIC code) and year.

\begin{tabular}{|l|c|c|c|c|}
\hline & \multicolumn{2}{|c|}{ High R\&D Expense } & \multicolumn{2}{c|}{ Low R\&D Expense } \\
\hline Variable & Estimate & p-value & Estimate & p-value \\
\hline Alpha & 0.305 & 0.041 & 0.118 & 0.523 \\
\hline RMRF & 0.165 & $<.0001$ & 0.005 & 0.925 \\
\hline SMB & 0.272 & $<.0001$ & 0.250 & $<.0001$ \\
\hline HML & -0.479 & $<.0001$ & -0.204 & 0.002 \\
\hline UMD & -0.105 & 0.001 & 0.008 & 0.824 \\
\hline Adj R-squared & 0.68 & & 0.27 & \\
\hline N & 179 & & 176 & \\
\hline
\end{tabular}

In a similar vein, Table 8 partitions the sample on advertising expenditures. Firms are classified as having high (low) profitability if the observation is in the top (bottom) two quartile ranks for that particular fiscal year and industry (three-digit SIC). Results suggest that CMOs have the greatest economic relevance among firms with high advertising expenditures $(\alpha=.292, p=.061)$, consistent with H6. Overall, we find that having a CMO in the TMT increases shareholder value, which is consistent with our first hypothesis. Further, we find that this effect manifests among firms with high operating margin, low asset turnover, high profitability, high R\&D intensity, and high advertising expenditures, which is consistent with our subsequent hypotheses.

Table 8: Value Premium of CMOs Across Advertising Expense

This table presents results from estimating the following time series regression: $\mathrm{CMO}_{\mathrm{t}}=\alpha+\beta_{1} \mathrm{RMRF}_{\mathrm{t}}+\beta_{2} \mathrm{SMB}_{\mathrm{t}}+\beta_{3} \mathrm{HML}_{\mathrm{t}}+$ $\beta_{4} \mathrm{UMD}_{\mathrm{t}}+\varepsilon_{\mathrm{t}} . \mathrm{CMO}_{\mathrm{t}}$ is a value-weighted monthly return from a zero-investment portfolio that purchases (sells) shares of firms with (without) a "Chief Marketing Officer" within the top five highly compensated executives as of the most recent fiscal year. All other variables are defined in Table 2. High (low) advertising expense is defined as firms that are in the top (bottom) two quartile ranks for each industry (using three-digit SIC code) and year.

\begin{tabular}{|l|c|c|c|c|}
\hline \multicolumn{1}{|c|}{ Variable } & High Advertising Expense & \multicolumn{2}{c|}{ Low Advertising Expense } \\
\hline Alpha & Estimate & p-value & Estimate & p-value \\
\hline RMRF & 0.292 & 0.061 & 0.071 & 0.746 \\
\hline SMB & 0.135 & 0.002 & 0.092 & 0.132 \\
\hline HML & 0.129 & 0.005 & 0.371 & $<.0001$ \\
\hline UMD & -0.271 & $<.0001$ & -0.431 & $<.0001$ \\
\hline Adj R-squared & -0.120 & 0.000 & -0.034 & 0.448 \\
\hline N & 0.42 & & 0.48 & \\
\hline
\end{tabular}

\section{CONCLUSION}

The purpose of this study is to examine whether having a CMO in the TMT contributes to firm value. Organizational theory suggests firms that have ascended their CMO position to the TMT may reflect a commitment to a consumer-centric strategy, and this commitment may have value implications because CMOs in the TMT are in a unique position to advise the CEO and other executives on firm strategy. However, prior literature has failed to document an association between CMO influence or power and firm performance (Boyd et al., 2010; Nath and Mahajan 2008; 2011). We find that CMOs do in fact matter for shareholder value. Our primary results indicate that the presence of a CMO in the TMT results in an annualized excess return of approximately three percent relative to firms without a CMO in the top management team. We document that our results manifest among firms with high operating margin, low asset turnover, high profitability, high R\&D expense, and high advertising expense. We 
conclude that the importance firms place on the CMO position has economic implications for long-term shareholder value.

Our paper contributes to the nascent literature on the influence of marketing in the TMT (Nath and Mahajan, 2008; Boyd et al., 2010; Nath and Mahajan, 2011). Our paper is the first to find a main effect of CMO presence in the TMT and firm value. Our paper differs from prior literature in that we use a larger cross-section of firms and we use a long-horizon approach to document that having a CMO in the TMT is beneficial to shareholders. We further document that this benefit manifests in firms where the role of the CMO is likely critical to firm performance; that is, firms with high operating margin, low asset turnover, high profitability, high R\&D activity, and high advertising expenditures.

Further, our study should be of interest to practitioners in the marketing profession, boards of directors, executives, and investors as to whether the CMO position offers tangible value to the organization. While some have argued that the CMO position is fading and losing its importance, others maintain that CMOs need to be involved in the strategic decision making process alongside the CEO and other top executives. Using our long-horizon specification, we document that having a CMO in the TMT is economically relevant.

Our paper is subject to limitations. First, we examine large (S\&P 1500) firms. Future research could examine the role of the CMO within smaller organizations. Further, our research design limits CMO influence to the top five highest paid executives. While this is consistent with prior literature (Finkelstein, 1992; Boyd et al., 2010), there may be firms where the CMO is just below the top five highest paid executives, wields significant power within the organization, but would not meet our definition of a "CMO firm." However, such instances should actually bias against us finding results.

\section{AUTHOR INFORMATION}

John Abernathy is an Assistant Professor of Accounting at Kennesaw State University. He earned his Ph.D in Accounting at the University of Alabama in 2010. His research interests are in the areas of financial reporting quality, auditing, corporate governance, and executive compensation. E-mail: jabern21@kennesaw.edu (Corresponding author)

Tom Kubick is an Assistant Professor of Accounting at the University of Kansas. He earned his Ph.D in Accounting at the University of Nebraska-Lincoln in 2011. His research interests are in the areas of corporate taxes, particularly tax avoidance and corporate tax finance. E-mail: tkubick@ku.edu

Adi Masli is an Assistant Professor of Accounting at the University of Kansas. He earned his Ph.D in Accounting at the University of Arkansas in 2011. His research interests are in the areas of financial reporting quality, auditing, internal controls, corporate governance, and executive compensation. E-mail: amasli@ku.edu

\section{REFERENCES}

1. Anderson, PF 1982. Marketing, strategic planning and the theory of the firm. Journal of Marketing 46(Spring): 15-26.

2. Banker, RD, Mashruwala, R., Tripathy A. 2006. Generic strategies and sustainability of financial performance. Working paper. Temple University.

3. Banks, G. 2009. Full potential, finally: the CMO's role in the modern corporation. CMO. 16 September. http://www.cmo.com/content/cmo-com/home/articles/2009/9/16/full-potential-finally-the-cmos-role-in-themodern-corporation.html

4. Barker, VL, Mueller, GC. 2002. CEO characteristics and firm R\&D spending. Management Science 48(June): 782-801.

5. Bertrand, M., Schoar, A. 2003. Managing with style: the effect of managers on firm policies. The Quarterly Journal of Economics 118(4): 1169-1208.

6. Bhoraj, S., Hribar, P., Picconi, M., McInnis, J. 2009. Making sense of cents: an examination of firms that marginally miss or beat analyst forecasts. Journal of Finance 64(5): 2361-2388. 
7. Boyd, DE, Chandy, RK. Cunha, M. 2010. When do chief marketing officers impact firm value? A customer power explanation. Journal of Marketing Research 47(December): 1162-1176.

8. $\quad$ Carhart, M. 1997. On persistence in mutual fund performance, Journal of Finance 52(1): 57-82.

9. Carpenter, MA., Sanders, WmG. 2002. Top management team compensation: the missing link between CEO pay and firm performance? Strategic Management Journal 23(4): 367-375.

10. Court, D. 2007. The evolving role of the CMO. McKinsey Quarterly 3(1): 28-39.

11. Currim, IS, Lim, J., Kim, JW. 2012. You get what you pay for: the effect of top executives' compensation on advertising and R\&D spending decisions and stock market return. Journal of Marketing 76(5): 33-48.

12. Cyert RM., March, JG. 1963. A Behavioral Theory of the Firm. 2nd ed. Prentice Hall, Englewood Cliffs, NJ.

13. Dixit, A., Norman, V. 1978. Advertising and welfare. The Bell Journal of Economics 9(1): 1-17.

14. Eisenhardt, KM, Bourgeois, LJ. 1988. Politics of strategic decision making in high-velocity environments: toward a midrange theory. Academy of Management Journal 31(December): 737-70.

15. Fairfield, P., Yohn, T. 2001. Using asset turnover and profit margin to forecast changes in profitability. Review of Accounting Studies 6(December): 371-385.

16. Fama, E., French, K. 1993. Common risk factors in the returns on bonds and stocks. Journal of Financial Economics 33(1): 3-53.

17. Finkelstein, S. 1992. Power in top management teams: dimensions, measurement, and validation. Academy of Management Journal 35(August): 505-538.

18. Finkelstein S, Hambrick D. 1996. Strategic Leadership: Top Executives and their Effects on Organizations. West: Minneapolis/St. Paul, MN

19. Forrester Research and Heidrick \& Struggles. 2011. The evolved CMO. A joint research project by Forrester Research and Heidrick \& Struggles. http://www.cmo.com/content/dam/CMO_Other/attachments/TheEvolvedCMO.pdf

20. Fournaise Marketing Group. 2011.73\% of CEOs think marketers lack business credibility. Fournaise Track-Media Releases. http://www.fournaisegroup.com/Marketers-Lack-Credibility.asp

21. Gompers, P., Ishii, J., Metrick, A. 2003. Corporate governance and equity prices. The Quarterly Journal of Economics 118(1): 107-156.

22. Gupta, AK., Raj, SP, Wilemon, D. 1986. A model for studying R\&D-marketing interface in the product innovation process. Journal of Marketing 50(April): 7-17.

23. Hambrick DC, Mason PA. 1984. Upper echelons: the organization as a reflection of its top managers. Academy of Management Review 9(2): 193-206.

24. Hise, RT. 1965. Have manufacturing firms adopted the marketing concept? Journal of Marketing 29(July): $9-12$.

25. Homburg, C., Workman, JP, Krohmer, H. 1999. Marketing's influence within the firm. Journal of Marketing 63(April): 1-17.

26. Hyde, P., Landry, E., Tipping, A. 2004. Making the perfect marketer. Strategy + Business 37(November 30): 37-43.

27. International Business Machines Corporation (IBM). 2011. From stretched to strengthened. CMO C-Suite Studies. http://ibm.com/cmostudy2011

28. Kald, M. 2003. Strategic Positioning: A Study of the Nordic Paper and Pulp Industry. Strategic Change, 12(6): 329-343.

29. Kotha, S., Nair, A. 1995. Strategy and environment as determinants of performance: evidence from the Japanese machine tool industry. Strategic Management Journal 16(7): 497-518.

30. Kotha, S., Vadlamani, B. 1995. Assessing generic strategies: an empirical investigation of two competing typologies in discrete manufacturing industries. Strategic Management Journal 16(1): 75-83.

31. Kumar, V., Shah, D. 2009. Expanding the role of marketing: from customer equity to market capitalization. Journal of Marketing 73(November): 119-136.

32. Larcker, D., Zakolyukina, A. 2012. Detecting deceptive discussions in conference calls. Journal of Accounting Research 50(2): 495-540.

33. Magnone, P. 2011. The CMO: dead man walking. Forbes. 10 November. http://www.forbes.com/sites/paulmagnone/2011/11/10/the-cmo-dead-man-walking/

34. Mann, J. 1971. Nominal and Effective Status of Chief Marketing Executives in Yorkshire Industry. In Exploration in Marketing Thoughts, G. Wills, ed. London: Crosby Lockwood, 268-76. 
35. McGovern, GJ., Quelch, JA. 2004. The fall and rise of the CMO. Strategy + Business. 37(Special Report): $1-8$.

36. Michel, JG., Hambrick, DC. 1992. Diversification posture and top management characteristics. Academy of Management Journal 35(March): 9-37.

37. Nath, P, Mahajan, V. 2008. Chief marketing officers: a study of their presence in firms' top management team. Journal of Marketing 72(1): 65-81.

38. Nath, P., Mahajan, V. 2011, Marketing in the C-Suite: a study of chief marketing officer power in firms' top marketing team. Journal of Marketing 75(1): 60-77.

39. Nissim, D., Penman, S. 2001. Ratio analysis and equity valuation: from research to practice. Review of Accounting Studies 6(1): 109-154.

40. Piercy, N. 1986. The role and function of the chief marketing executive and the marketing department. Journal of Marketing Management 2(3): 265-289.

41. Porter, M. (1980), Competitive Strategy, New York: Free Press.

42. Porter, M. 1996. What is strategy? Harvard Business Review. Nov-Dec: 59-79.

43. Rao, R., Bharadwaj, N. 2008. Marketing initiatives, expected cash flows, and shareholders' wealth. Journal of Marketing 72(January): 16-26.

44. Roberts, J. 2012. Death of the CMO? MarketingWeek. December. http://www.marketingweek.co.uk/strategies-and-tactics/death-of-the-cmo/4004856.article

45. Roll, M. 2011. The chief marketing officer's new boardroom role. The Insight Bureau Briefings. http://www.insightbureau.com/insight articles/FTDO.No62.MartinRoll.Jul11.pdf

46. Selling, T., Stickney, C. 1989. The effects of business environment and strategy on a firm's rate of return on assets. Financial Analysts Journal (January-February): 43-68.

47. Silver, S. 2003. Bring on the super-CMO. Strategy + Business 31(Summer): 1-5.

48. Slater SF., Olson, EM. 2001. Marketing's contribution to the implementation of business strategy: an empirical analysis. Strategic Management Journal 22(11): 1055-1068.

49. Smith, J. 2012. America's highest-paid CMOs. Forbes. 27 March. http://www.forbes.com/sites/jacquelynsmith/2012/03/27/americas-highest-paid-cmos/

50. Smith, J. 2013. America's highest-paid marketing executives. Forbes. 27 March. http://www.forbes.com/sites/jacquelynsmith/2013/03/27/americas-highest-paid-marketing-executives/

51. Spencer Stuart. 2004. CMO tenure: slowing down the revolving door. Spencer Stuart Blue Paper Series. http://content.spencerstuart.com/sswebsite/pdf/lib/CMO brochureU1.pdf

52. Srivastava, RK, Shervani, TA, Fahey, L. 1998. Market-based assets and shareholder value: a framework for analysis. Journal of Marketing 62(January): 2-18.

53. Srivastava, RK, Shervani, TA, Fahey, L. 1999. Marketing, business processes and shareholder value: an organizationally embedded view of marketing activities and the discipline of marketing. Journal of Marketing 63(Special issue): 168-179.

54. Turpin, D. 2012. The CMO is dead. Forbes. 3 October. http://www.forbes.com/sites/onmarketing/2012/10/03/the-cmo-is-dead/

55. Varadarajan, PR, Clark, T. 1994. Delineating the scope of corporate and marketing strategy. Journal of Business Research 31(October-November): 93-105.

56. Webster, FE. 1981. Top management's concerns about marketing: issues for the 1980's. Journal of Marketing 45(Summer): 9-16.

57. Webster, FE. 1992. The changing role of marketing in the corporation. Journal of Marketing 56(October): $1-17$.

58. Webster, FE., Malter AJ, Ganesan, S. 2003. Can marketing regain its seat at the table? MSI Report No. 03003. Cambridge, MA: Marketing Science Institute: 29-49.

59. Weinzimmer, LG., Bond, EU, Houston, MB, Nystrom, PC. 2003. Relating marketing expertise on the top management team and strategic market aggressiveness to financial performance and shareholder value. Journal of Strategic Marketing 11(2): 133-159

60. Yadav, MS., Prabhu, JC, Chandy, R. 2007. Managing the future: CEO attention and innovation outcomes. Journal of Marketing 71(October): 84-101.

61. Zmuda, N. 2009. Why the CMO role is not as important as you think. Advertising Age. 18 June. http://adage.com/print/137410 